\title{
IMPROVING THE ABILITY OF WRITING EXPOSITION TEXT USING DISCOVERY LEARNING LEARNING MODEL CLASS VIII STUDENTS OF SMP NEGERI 5 MANDREHE STUDY YEAR 2020/2021
}

\begin{abstract}
Theodorius Bastian "Universitas
Gulo $^{1+}$

Email: -
\end{abstract}

(+ Corresponding author)

Article History
Received:
Revised:
Accepted:
Published:
Keywords
writing, exposition text, discovery
learning
learning

\begin{abstract}
This research was motivated by the existence of problems in learning to write that occurred in junior high schools, especially in writing exposition texts. The purpose of this study was to determine the increase in the ability to write an exposition text using the discovery learning model of class VIII students at SMP Negeri 5 Mandrehe. The method used in this research is designed with classroom action research. The results showed that the students' exposition writing ability using discovery learning method had a significant increase. Judging from the increasing average results of students, it can be concluded that the use of the Discovery Learning method is suitable for learning to write exposition text
\end{abstract}

\section{PRELIMINARY}

Language skills are very important to be mastered by students. These language skills include listening, reading, speaking and writing. Writing is a person's ability to express ideas, ideas or images in the human mind in the form of written works that can be read, understood and understood by others.

Every student is expected to be able to carry out writing activities because writing skills are very important for students. Writing is used by students to take notes or record, convince, report or inform, and influence. The purpose and purpose of writing can be achieved well by someone who can compose ideas, thoughts, arguments, and express them clearly. This clarity depends on the reasoning, organization, language, spelling, and punctuation used.

Tarigan (2005: 22) says that writing is very important for someone because it makes it easier to think, feel and enjoy relationships, deepens responsiveness or perceptions of solving problems at hand and also arranges sequences for his experiences.

The 2013 Curriculum Content Standards consist of four Core Competencies (KI), namely religious attitudes, social attitudes, knowledge, and skills. Each of these Core Competencies has several Basic Competencies (KD). Specifically for the basic competencies of knowledge and skills, there are several types of new texts that have been mentioned. These texts are teaching materials that need to be taught to students. There are several activities in these Basic Competencies, namely understanding, converting, summarizing, producing. Activities that become Basic Competencies or 
things that must be mastered by students. Some of these activities are always manifested either orally or in writing.

One of the texts contained in the 2013 curriculum, namely the exposition text. Exposition text means an essay whose main purpose is to inform, analyze, describe, or explain something (Suparno 2008: 5.4). Exposition text also means text that is used to propose a personal opinion about something (Maryanto 2014: 92).

Exposition text contains the opinion to be conveyed, the writing must also use good and correct sentences. Students must be able to formulate ideas through narrative sentences that are well arranged, accurate, and polite so that they are easy to understand and do not cause misinterpretation. However, there are still many students who are not careful in expressing their opinions in the field. One of them is SMP Negeri 5 Mandrehe. Students of SMP Negeri 5 Mandrehe are very active in writing activities but the structure of the Indonesian language used at the time of writing is still lacking. This contrasts with the skills that must be mastered in producing exposition text. Students of SMP Negeri 5 Mandrehe are not careful in writing the exposition text because of their inadequate ability to use Indonesian correctly and communicatively.

Some things that cause the low writing ability of class VIII students according to Indonesian language subject teachers, namely, learning to write exposition texts is carried out conventionally. In this context, students are given a theory of writing an exposition text then see examples and are finally assigned to make a procedural text. This is reinforced by the fact that the teacher does not introduce various media or learning resources. Teacher learning resources that can be used by students are Indonesian language textbooks. Therefore, the atmosphere of teaching and learning about writing skills becomes boring and students feel bored following the learning process.

Based on these conditions, it is necessary to have an alternative learning to write an exposition text to get a learning process that can increase enthusiasm, interest and motivate students, the ability to express ideas, the ability of students to write exposition text. In this case using discovery learning model. Discovery occurs when the individual is primarily involved in the use of his mental processes to discover some concepts and principles.

In addition, the problem that often occurs in class is that students' interest in writing is very lacking, so they will prefer to speak out their ideas and thoughts. From these problems, we need a learning model that can overcome problems in learning to write. The low ability to write the text according to the results of interviews with the material teacher was caused by the low interest of students in writing exposition texts. The limited ability of students to find the right idea in writing an exposition text. The use of learning models that are not varied. Lack of students' understanding of EYD and correct writing so that students find it difficult to write exposition.

\section{Exposition Text}

An exposition text is a text that explains a subject that can broaden the reader's horizons. To emphasize the problem presented, it is usually equipped with pictures and statistical data. The goal is for readers to receive information and knowledge as clearly as possible (https://www.studiobelajar.com/teks-eksposisi/) 
IJEMS: Indonesian Journal of Education and Mathematical Science

2021 Vol. 1, No. 1, pp. 11-18

$\operatorname{ISSN}(e): 2715-985 x$

DOI: https://doi.org/10.30596/ijems.v1i3.2602

(C)2020IJEMS@UMSU.All Rights Reserved.

\section{Discovery Learning Model}

According to Kurniasih, et al (2014: 64), discovery learning is a learning activity where material is delivered directly to students. Furthermore, students are encouraged to manage the material independently. Where they must be able to find concepts based on data or information by means of research

Based on Ruseffendi (2006: 329), discovery learning model is a model that manages learning that can make students gain knowledge independently and are not actively known by themselves.

(https://www.tripven.com/discovery-learning/)

Based on the above opinion, it can be concluded that the discovery learning model is a learning model that manages learning and is conveyed directly so that students can gain knowledge independently and are not known by themselves actively.

\section{RESEARCH METHODS}

In connection with the main objective of this study, namely to describe the planning, implementation process, and increasing the ability to read exposition text through the application of the discovery learning model in grade VIII students of SMP Negeri 5 Mandrehe, this research can be categorized as classroom action research. The variables in this study were the increase in the ability to write exposition text by applying the discovery learning model to the eighth grade students of SMP Negeri 5 Mandrehe and the process of applying the discovery learning model in learning to read the exposition text. The research design used by the researcher is the Kurt Lewin model which begins with planning, acting, observing, and reflecting. The research flow of the Kurt Lewin model The population in this study were all class VIII students, while the sample of this study was 24 students of class VIII SMP Negeri 5 Mandrehe totaling 24 people in the 2020/202 1 school year. The research instruments used in this study were the observation sheet and the test sheet. The data obtained in this study are process and outcome data. To obtain data in this study, observation sheets and assignments were used. The research data analysis technique was carried out by using qualitative and quantitative descriptive analysis to measure the students' ability to write an exposition text based on the data obtained, namely the process and outcome data. Process data were analyzed by describing the activities of teachers and students in learning, while data on student learning outcomes were analyzed quantitatively. The indicator of the success of this study is if the percentage of student learning completeness reaches $85 \%$ collectively which is indicated by the specified minimum completeness criteria, namely 68.

\section{RESEARCH RESULTS AND DISCUSSION}

Based on the background, problem formulation, research objectives, research benefits, literature review, and research methods that have been described previously, this section will explain the results of research by applying discovery learning learning models as an effort to improve the writing ability of students of class VIII SMP. Negeri 5 Mandrehe. 


\section{A. Cycle Research Results 1}

\section{Planning}

The action research carried out at this stage is as follows.

a) Researchers determine the appropriate model to improve students' expression text writing skills, namely by applying the Discovery Learning learning model. b) After planning the implementation of learning by applying the Discovery Learning learning model, the researcher also chooses an approach that is able to support the implementation of research, namely the scientific approach.c) Determine the steps for implementing learning. d) Prepare learning materials and instruments in the form of assessment sheets for writing exposition text. e) Determine the timing of the action, namely two meetings in one cycle ( 2 x 40 minutes).

\section{Action}

The implementation of the action through the application of the Discovery Learning learning model is expected to improve the writing skills of the eighth grade students of SMP Negeri 5 Mandrehe. In carrying out this action, two meetings were held ( 2 x 40 minutes).

The first meeting

At the first meeting of cycle one, the teacher begins learning by conveying back the core competencies and basic competencies as well as indicators that students must achieve. After that, explain the learning steps to be carried out. Besides the teacher explaining the material, the teacher also motivates students to be able to write exposition texts. Furthermore, students read and observe an exposition text. Participants identify and examine the structure of the exposition text. Ask what is not known about the exposition text, collect information and examine the information found in the exposition text. Furthermore, presenting the results of the discussion about the exposition text and concluding.

\section{Second meeting}

At this second meeting the teacher re-directs and guides students to pay attention to linguistic and non-linguistic aspects. The teacher relays the exposition text material and carries out a question and answer process related to the material. Then develop an exposition text based on a structure in the form of a thesis, a series of arguments and reaffirmation.

The teacher also provides motivation to each student who compiles the exposition text so that they are more enthusiastic and confident.

\section{Observations}

After carrying out the action, the teacher made careful observations of the actions that had been taken in cycle I. The observation results included two parts, namely observing the process and observing the product. Observation in the process includes the activities of students as research 
IJEMS: Indonesian Journal of Education and Mathematical Science

2021 Vol. 1, No. 1, pp. 11-18

$\operatorname{ISSN}(e): 2715-985 x$

DOI: https://doi.org/10.30596/ijems.v1i3.2602

(C)2020IJEMS@UMSU.All Rights Reserved.

subjects in the implementation of writing text exposition and response to learning water. Observation by product in the form of scores obtained by students from writing the exposition text

\section{a. Process Observation}

During the learning process, students pay close attention to what is conveyed by the teacher, some students who previously had difficulty writing the exposition text, after carrying out the action, they can compile the exposition text based on its structure. The monitoring results also showed that there was a change in behavior marked by the behavior of students who had difficulty conveying their ideas, after being given the first cycle they were finally able to write the exposition text well, although in some aspects there were still things that needed to be improved. In addition, the role of the teacher also determined in the process of student success when learning the teacher can do their job well; directing students, controlling the class to remain conducive and motivating students to perform optimally. When learning takes place, the teacher always gives students the opportunity to ask questions that are still not understood and still feel difficult.

\section{b. Product Observations}

The success of the action in the product can be seen from the acquisition of a test score in cycle I. This observation was made when the students wrote the exposition text.

The changes in the results that have been achieved in learning to write exposition text with the application of the Discovery Learning learning model are the increasing skills of students to write exposition text. The following is a table of student scores in cycle 1

Table of Students' Exposition Text Writing Skills Score Table I.

\begin{tabular}{|c|c|c|c|c|c|}
\hline \multirow{2}{*}{ CODE } & \multicolumn{3}{|l|}{ ASPECT OF ASSESSMENT } & \multirow{2}{*}{$\begin{array}{l}\text { TOTAL } \\
\text { SCORE }\end{array}$} \\
\cline { 2 - 5 } & 1 & 2 & 3 & 4 & \\
\hline S1 & 15 & 22 & 17 & 18 & 72 \\
\hline S2 & 19 & 19 & 20 & 17 & 75 \\
\hline S3 & 20 & 14 & 15 & 17 & 66 \\
\hline S4 & 20 & 19 & 18 & 21 & 78 \\
\hline S5 & 20 & 21 & 20 & 19 & 80 \\
\hline S6 & 19 & 15 & 19 & 17 & 70 \\
\hline S7 & 17 & 16 & 15 & 14 & 62 \\
\hline S8 & 18 & 15 & 14 & 22 & 69 \\
\hline S9 & 17 & 14 & 15 & 18 & 64 \\
\hline S10 & 20 & 16 & 16 & 16 & 68 \\
\hline S11 & 15 & 16 & 14 & 19 & 64 \\
\hline
\end{tabular}


IJEMS: Indonesian Journal of Education and Mathematical Science

2021 Vol. 1, No. 1, pp. 11-18

$\operatorname{ISSN}(e): 2715-985 x$

DOI: https://doi.org/10.30596/ijems.v1i3.2602

(C)2020IJEMS@UMSU.All Rights Reserved.

\begin{tabular}{|c|c|c|c|c|c|}
\hline S12 & 20 & 14 & 22 & 20 & 76 \\
\hline S13 & 21 & 20 & 19 & 21 & 81 \\
\hline S14 & 19 & 18 & 20 & 19 & 76 \\
\hline S15 & 21 & 19 & 20 & 19 & 79 \\
\hline S16 & 18 & 15 & 14 & 15 & 62 \\
\hline S17 & 20 & 21 & 20 & 21 & 82 \\
\hline S18 & 21 & 14 & 19 & 17 & 71 \\
\hline S19 & 15 & 20 & 20 & 19 & 74 \\
\hline S20 & 21 & 19 & 20 & 19 & 79 \\
\hline S21 & 21 & 20 & 19 & 22 & 82 \\
\hline S22 & 14 & 18 & 18 & 19 & 69 \\
\hline S23 & 18 & 16 & 19 & 20 & 73 \\
\hline S24 & 17 & 15 & 19 & 14 & 65 \\
\hline TOTAL & 446 & 416 & 432 & 443 & 1737 \\
\hline AVERAGE & 18.583 & 17.333 & 18 & 18.458 & 72.375 \\
\hline
\end{tabular}

The results obtained from cycle I both in process and product have shown a good enough improvement even though there are still shortcomings. These deficiencies are caused by several obstacles faced during the action.

The constraints found by researchers are as follows.

a. Students' understanding of the exposition text is still not in accordance with the instructions, some students are still confused about how to write the exposition text

b. The composition of the exposition text lacks the structure and characteristics of the exposition text

c. The ideas in the preparation of the exposition text still need development.

Reflections carried out both in process and product indicate an increase and a shortage. The shortcomings or constraints that occur during the first cycle will be the basis for the implementation of the next cycle so that it is expected that the next cycle will increase significantly.

\section{Reflection}

After the cycle I action process ends, the researcher analyzes the results of the action or performance test, observation, interviews, journals, and documentation. Reflection is an activity to review, see, and consider the learning outcomes of the actions taken to analyze test and non-test results. Reflection is carried out after action is carried out in cycle I learning. Reflection is carried out through discussions between teachers, students, and researchers about various problems that occur.

The results of the action in cycle I aim to determine the strengths and weaknesses of the collaborative patterns and learning models used. Does using discovery learning model improve students' ability to write exposition text 
IJEMS: Indonesian Journal of Education and Mathematical Science

2021 Vol. 1, No. 1, pp. 11-18

$\operatorname{ISSN}(e): 2715-985 x$

DOI: https://doi.org/10.30596/ijems.v1i3.2602

(C)2020IJEMS@UMSU.All Rights Reserved.

\section{B. Cycle II Research Results \\ 1. Planning}

The planning of the second cycle class action research aims to improve the aspects of exposition writing that have not been fulfilled in cycle I learning. This is also to find solutions to the obstacles faced by students in the exposition writing process in cycle I, so that maximum results are achieved. The implementation planning carried out in cycle II is as follows.

a. Prepare exposition writing material that will be presented to students.

b. Prepare a learning implementation plan (RPP) compiled by the researcher

c. Prepare an exposition writing skill test sheet.

d. Prepare field notes and documentation tools as data recorders.

e. Teachers provide more motivation to increase enthusiasm, effectiveness, and attention or focus of students in following the learning process of writing exposition text. This is done because there are students who have not focused on the learning process.

f. The teacher asks students to pay more attention to the writing system and neatness of students' writing

\section{Action}

At this stage, the implementation of the action is the same as the implementation in cycle I, which takes place for 2 meetings by observing all teacher and student behavior in each meeting based on the observation sheet that has been made. The time allocation for each meeting is 2 x 40 minutes and is divided into three activities, namely preliminary activities, core activities, and closing activities.

\section{Observations}

Observations were made by the researcher when the learning process was writing exposition using the discovery learning model. Observations in cycle II use the same research instruments as research in cycle I. The results obtained from these observations include the impact on the learning process (process success) and the impact of action on learning outcomes (product success). The impact of both process success measures and product success can be described as following.

a) Process success

In observing the learning process, researchers used observation guidelines that were focused on teaching and learning situations. What is observed from the teaching-learning situation is the positive and negative behavior of students towards the attention, participation, response, and activeness of students in answering questions.

b) Product Success 
IJEMS: Indonesian Journal of Education and Mathematical Science

2021 Vol. 1, No. 1, pp. 11-18

$\operatorname{ISSN}(e): 2715-985 x$

DOI: https://doi.org/10.30596/ijems.v1i3.2602

(C)2020IJEMS@UMSU.All Rights Reserved.

The success of the product in the second cycle can be seen through the results of the acquisition of scores in exposition writing learning using discovery learning models. The scores for exposition writing using the discovery learning learning model can be seen in the following table:

Table of Student's Exposition Text Writing Skills Score Cycle II

\begin{tabular}{|c|c|c|c|c|c|}
\hline \multirow[b]{2}{*}{ CODE } & \multicolumn{4}{|c|}{ ASPECT OF ASSESMENT } & \multirow{2}{*}{$\begin{array}{l}\text { TOTAL } \\
\text { SCORE }\end{array}$} \\
\hline & 1 & 2 & 3 & 4 & \\
\hline S1 & 20 & 21 & 22 & 21 & 84 \\
\hline S2 & 21 & 19 & 18 & 20 & 78 \\
\hline S3 & 19 & 22 & 19 & 17 & 77 \\
\hline $\mathrm{S} 4$ & 22 & 21 & 20 & 18 & 81 \\
\hline $\mathrm{S} 5$ & 20 & 22 & 21 & 19 & 82 \\
\hline S6 & 18 & 17 & 20 & 21 & 76 \\
\hline $\mathrm{S} 7$ & 17 & 19 & 17 & 19 & 72 \\
\hline $\mathrm{S} 8$ & 20 & 17 & 22 & 17 & 76 \\
\hline S9 & 18 & 20 & 19 & 20 & 77 \\
\hline $\mathrm{S} 10$ & 20 & 22 & 23 & 20 & 85 \\
\hline $\mathrm{S} 11$ & 19 & 16 & 15 & 19 & 69 \\
\hline $\mathrm{S} 12$ & 20 & 22 & 20 & 20 & 82 \\
\hline $\mathrm{S} 13$ & 20 & 22 & 23 & 21 & 86 \\
\hline $\mathrm{S} 14$ & 20 & 18 & 21 & 19 & 78 \\
\hline $\mathrm{S} 15$ & 21 & 22 & 20 & 20 & 83 \\
\hline $\mathrm{S} 16$ & 19 & 19 & 18 & 22 & 78 \\
\hline $\mathrm{S} 17$ & 21 & 20 & 22 & 21 & 84 \\
\hline $\mathrm{S} 18$ & 20 & 22 & 20 & 17 & 79 \\
\hline $\mathrm{S} 19$ & 22 & 22 & 19 & 21 & 84 \\
\hline $\mathrm{S} 20$ & 22 & 22 & 20 & 22 & 86 \\
\hline $\mathrm{S} 21$ & 22 & 23 & 21 & 22 & 88 \\
\hline $\mathrm{S} 22$ & 20 & 19 & 22 & 20 & 81 \\
\hline $\mathrm{S} 23$ & 19 & 22 & 19 & 21 & 81 \\
\hline $\mathrm{S} 24$ & 20 & 21 & 19 & 22 & 82 \\
\hline TOTAL & 480 & 490 & 480 & 479 & 1929 \\
\hline AVERAGE & 20 & 20.416 & 20 & 19.958 & 80.37 \\
\hline
\end{tabular}

The success of the product can be seen from the students' exposition writing on the second cycle of action. The results of the second cycle were then compared with the results obtained in the action cycle I. The improvement of learning exposition writing occurred in cycle II with an average score of 
IJEMS: Indonesian Journal of Education and Mathematical Science

2021 Vol. 1, No. 1, pp. 11-18

$\operatorname{ISSN}(e): 2715-985 x$

DOI: https://doi.org/10.30596/ijems.v1i3.2602

(C)2020IJEMS@UMSU.All Rights Reserved.

80.37. In the action cycle I only reached an average score of 72.37. This shows that there has been an increase of 8.00 .

\section{Reflection}

Reflection cycle II was carried out to determine the effectiveness of discovery learning learning models in improving the ability to write exposition text. Reflection in the second cycle is carried out to reflect on the results of the learning evaluation of students. Reflection aims to determine the progress that has been achieved during the learning process and to look for weaknesses that arise in learning. In addition, the results of reflection in cycle II aim to determine the increase in the ability of students after the improvement of learning in cycle I reflection. The progress achieved in cycle II was an increase in the ability to write exposition text and changes in student behavior in a positive direction.

\section{CONCLUSION}

Based on the results of the analysis and discussion of this classroom action research, it can be concluded that the application of discovery learning can actually improve the writing skills of the eighth grade students of SMP Negeri 5 Mandrehe. This is shown from the planning, implementation, observation, and evaluation results of writing the exposition text in cycle I and cycle II.

\section{SUGGESTIONS AND RECOMMENDATIONS}

Based on the conclusions of the research results in improving the skills of composing an exposition text with a discovery learning model in class VIII students of SMP Negeri 5 Mandrehe, the researcher provides the following suggestions.

1. For Indonesian teachers, discovery learning models can be used as an alternative model for learning to write exposition texts

2. For students, discovery learning models can be used as a method to practice improving their writing ability in exposition text.

3. Researchers in the field of language education can carry out similar research in the field of writing skills, especially writing exposition texts using different models, methods, techniques, and media so that they can be another alternative for teaching exposition text writing skills.

\section{BIBLIOGRAPHY}

https://seputarilmu.com

https://www.studiobelajar.com/teks-eksposisi/ https://www.tripven.com/discovery-learning/ 
IJEMS: Indonesian Journal of Education and Mathematical Science

2021 Vol. 1, No. 1, pp. 11-18

$\operatorname{ISSN}(e): 2715-985 x$

DOI: https://doi.org/10.30596/ijems.v1i3.2602

(C)2020IJEMS@UMSU.All Rights Reserved.

https://www.passakanawang.com/2017/07/langkah-langkah-penerapan-model.html

https://www.pelajaran.co.id/2020/04/discovery-learning.html

https://www.pelajaran.co.id/2019/15/pengertian-ptk-tujuan-karakteristik-prinsip-langkah-danmodel-penelitian-tindakan-kelas-ptk.html

Sumarni, Sri, 2012, Metodologi Penelitian Pendidikan, Insan Madani, Yogyakarta

Tarigan, Henri Guntur, 2005, Menulis sebagai Suatu Keterampilan Berbahasa, Angkasa ,Bandung

Tim Penulis, 2017, Bahasa Indonesia Kelas VIII, Kemdikbud, Jakarata 